\title{
New Zinc (II) Phthalocyanines Substituents: Synthesis, Characterization, Aggregation Behavior, Electronic and Antibacterial Properties
}

\author{
Abdennasser JLALI ${ }^{1}$, Cherif JABLAOUI ${ }^{2}$, Mesbah LAHOUEL ${ }^{3}$, Bassem JAMOUSSI ${ }^{4}$ \\ ${ }^{1}$ Laboratory of Supramolecular Chemistry ISEFC, Faculty of Sciences Bizerte, University of Carthage.Tunisia \\ ${ }^{2}$ National Agronomic Institute of Tunisia (INAT), University of Carthage, Tunisia \\ ${ }^{3}$ Laboratory of Toxicology Molecular, University, Jijel-Algeria \\ ${ }^{4}$ Laboratory of Supramolecular Chemistry ISEFC, University Virtual-Tunisia
}

\begin{abstract}
This work reports on the synthesis of zinc (II) phthalocyanines bearing 4-((furan-2-ylmethyl)thio) and 4-((furan-2-ylmethyl) sulfonyl) substituents at peripheral position. The structure of the new zinc (II) phthalocyanines was elucidated by using nuclear magnetic resonance spectroscopy $\left({ }^{1} \mathrm{H} N M R,{ }^{13} \mathrm{C} N M R\right)$, infrared $(\mathrm{IR})$ and $U V$-visible spectroscopy. The aggregation state of two phthalocyanines synthesized in organic solvents such as dichloromethane, dimethylformamide and dimethyl sulfoxide was analysed in correlation with its photochemical behavior. General trends were described for the antimicrobial activity of synthesized zinc (II) phthalocyanines derivates screened against a wide range of Gram-positive and Gram-negative bacteria showed modest zone of inhibition.
\end{abstract}

Keywords: Zinc (II) phthalocyanines, Synthesis, aggregation, antibacterial activity

\section{Introduction}

The chemistry of the supramolecular phthalocyanine complexes have been the subject of many studies. Applications in medicine and biology have shown the great importance of phthalocyanine molecules such as photosensitizers for photodynamic therapy [1]. Wide variety of the nature and pattern of substituents of phthalocyanines has attracted a great deal of attention due to their effect on the photophysical properties and their interaction with cells and tissues, leading to different photobiological effects [2]. The phthalocyanines compounds have in the presence of oxygen water and light irradiation, an exceptionally broad spectrum of activity against micro-organisms, such as the result of photode-activation [3]. Thus, it is possible to combat, in particular, Gram-positive and Gram-negative bacteria and to protect diverse substrates against these bacteria' attack. Furthermore, these compounds are known for their di-oxygen transports and various redox transformations with proteins [4]. These biodegradable compounds are capable of generating singlet oxygen upon interaction with light of suitable wavelength; they also have strong biocidal effect on algae, bacteria, fungi and yeasts [5], [9]. Phthalocyanines are traditionally industrialized with widespread applications such as catalysts for oxidative degradation of various pollutants with oxygen and under light irradiation [10], molecular electronic devices [11] and optical recording materials [12], [13]. Also, metal phthalocyanine derivatives are known to exhibit high electron transfer properties. The electron transfer properties of phthalocyanines depend on the kind and the number of the substituents due to the interaction between the phthalocyanine ring and the metal center which is influenced by the conjugated 18 -л electrons of the phthalocyanine ring [14], [15]. Aggregation resulted in failure of some of the
ZnPc derivatives to protonate. In fact, the addition of protonating agents to aggregated $\mathrm{ZnPc}$ derivatives resulted in increase of aggregation followed by slow degradation [16]. In this regard, synthetic strategies to produce thionyl and sulfonyl linked phthalocyanine derivatives with good solubility and low aggregation have been undertaken especially which proves to possess more pronounced biological and better pharmacological activity [17], [18].The synthetic strategy involves metallophthalocyanines moiety as a scaffold for our complexes thereby, these complexes would exhibit desirable therapeutic properties of biological evolution.

In this work, we reported the synthesis of phthalocyanine containing 4-((furan-2-ylméthyl) thio) and 4-((furan-2ylméthyl) sulfonyl) substituents, Their $Q$ bands appeared at around 613-689 $\mathrm{nm}$. These compounds are finely soluble in organic solvents, and are target synthesized compounds characterized by FT-IR, ${ }^{1} \mathrm{H}$ NMR, and UV-visible spectroscope. In addition, the aggregation state of two phthalocyanines synthesized in organic solvents such as dichloromethane, dimethylformamide and dimethyl sulfoxide was analyzed in correlation to its photochemical behavior. The newly synthesized metallophthalocyanines possess modest activity in terms of antibacterial activity against various Gram-positive and Gram-negative bacteria.

\section{Experimental}

\subsection{Materials}

N,N-dimethylformamide (DMF), dimethylsulfoxide (DMSO), dichloromethane (DCM), 1-pentanol, n-hexane, chloroform $\left(\mathrm{CHCl}_{3}\right)$ and ethanol $\left(\mathrm{C}_{2} \mathrm{H}_{5} \mathrm{OH}\right)$ were freshly used (potassium carbonate $\left(\mathrm{K}_{2} \mathrm{CO}_{3}\right)$, sodium sulfate 


\section{International Journal of Science and Research (IJSR) \\ ISSN (Online): 2319-7064}

Index Copernicus Value (2013): 6.14 | Impact Factor (2015): 6.391

$\left(\mathrm{Na}_{2} \mathrm{SO}_{4}\right)$, sodium sulfite $\left(\mathrm{Na}_{2} \mathrm{SO}_{3}\right)$, zinc acetate $\left(\mathrm{Zn}(\mathrm{OAc})_{2}\right)$, 1,8-diazabicyclo[5.4.0] undec-7-ene (DBU) and thiols were used as received from Aldrich. 4- nitrophtalonitrile was synthesized in our laboratory starting with the phthalimide according to the literature procedure [19].

${ }^{1} \mathrm{H}-\mathrm{NMR}$ and ${ }^{13} \mathrm{C}-\mathrm{NMR}$ spectral data were obtained by Varian 300 FT-NMR. Spectrometer FTIR spectra were acquired on a Perkin-Elmer BX FT-IR system spectrometer by dispersing sample in $\mathrm{KBr}$ pellets. UV-Visible absorption spectra were recorded on a Cary 2300 spectrophotometer. Mass spectra were obtained using an Autoflex III ( Bruker) with electron impact (EI) ionization methods. Elemental analysis was done using a Vario-Elementar Microcube EL III. Mass spectral data were collected with a Bruker Autoflex III Smartbeam TOF/TOF Mass spectrometer.

\subsection{Synthesis}

\subsubsection{4-((furan-2-ylméthyl) thio) phthalonitrile (3)}

A mixture of 4-nitrophthalonitrile $1(2.5 \mathrm{~g}, 14.45 \mathrm{mmol})$ and furan-2-méthylthiol $2(1.65 \mathrm{~g}, 14.45 \mathrm{mmol})$ in $10 \mathrm{~mL}$ DMSO was stirred at room temperature under nitrogen atmosphere. After stirring for $15 \mathrm{~min}$, dry potassium carbonate $\mathrm{K}_{2} \mathrm{CO}_{3}(2$ $\mathrm{g}, 14.5 \mathrm{mmol}$ ) was added in small portions during $2 \mathrm{~h}$ with efficient stirring. The mixture was stirred under nitrogen atmosphere at room temperature for $48 \mathrm{~h}$. Water $(50 \mathrm{~mL})$ was added, and the product was extracted with DCM $(3 \times 50$ $\mathrm{mL})$. The organic phase was washed with water $(3 \times 50 \mathrm{~mL})$ and dried over sodium sulfate. The solvent was removed under reduced pressure, and the residue was recrystallized from ethanol to give 4-((furan-2-ylmethyl) thio) phthalonitrile 3. Yield: (90\%). Mp: $130{ }^{\circ} \mathrm{C} .{ }^{1} \mathrm{H}$ NMR(300 $\left.\mathrm{MHz}, \mathrm{CDCl}_{3}\right): \delta$, ppm: 7.7 (s, 1, H-Ar); 7,5-7.6 (2d, 1, HAr); 7,3 (d,1, H-Ar); 6,4 (m, 1, H-Ar); 6,2 (d,1, H-Ar); 4,2 (s, $\left.2, \mathrm{H},-\mathrm{CH}_{2}\right) ;{ }^{13} \mathrm{C} \mathrm{NMR}\left(75 \mathrm{MHz}, \mathrm{CDCl}_{3}\right): \delta, \mathrm{ppm}: 153.3$, $142.8,141.8,135.4,134.9,130,118.2,116,113.2,110$, 106.2, 39.4 FTIR max/cm ${ }^{-1}: 3005(\mathrm{C}-\mathrm{H}), 2226(\mathrm{C}-\mathrm{N}), 1668$, 1583 (C-C), 1437, 1408, 1387 (C-H), 730 (C-S-C).

Anal calculated for $\mathrm{C}_{13} \mathrm{H}_{8} \mathrm{ON}_{2} \mathrm{~S}: \mathrm{C}, 65.00 ; \mathrm{H}, 3.33 ; \mathrm{N}, 11.67$; S, 13.33\%; Found: C, 64.99; H, 3.35 N, 11.71; S, 13.38.\%. Mass m/z (EI, $30 \mathrm{eV}): \mathrm{M}^{+} 240$.

\subsubsection{4-((furan-2-ylméthyl) sulfonyl) phthalonitrile (4)}

To have a solution of 4-((furan-2-ylmethyl) thio) phthalonitrile 3 ( $2 \mathrm{~g}, 15.06 \mathrm{mmol})$ in $8.5 \mathrm{~mL}$ dry DCM cooled at $0{ }^{\circ} \mathrm{C}, m$-chloroperbenzoic acid $(6.35 \mathrm{~g}, 36.75$ $\mathrm{mmol})$ in DCM $(150 \mathrm{~mL})$ was slowly added. The mixture was warmed to room temperature and vigorously stirred at this temperature overnight $(12 \mathrm{~h})$. A saturated sodium sulfite solution was then added, and the organic phase was extracted with DCM $(3 \times 50 \mathrm{~mL})$ and dried over $\mathrm{Na}_{2} \mathrm{SO}_{4}$. The solvent was removed under reduced pressure, and the solid was recrystallized from ethanol to give 4-((furan-2-ylmethyl) sulfonyl) phthalonitrile 4 as a white solid. Yield: (84\%). Mp: $140^{\circ} \mathrm{C} .{ }^{1} \mathrm{H} \mathrm{NMR}\left(300 \mathrm{MHz}, \mathrm{CDCl}_{3}\right): \delta$, ppm: 8.6 (s, 1, H-Ar); 8,4 (1d, 1, H-Ar); 8,2 (1d, 1, H-Ar);7,5 (d, 1, H-Ar); 6,5 (m, 1, H-Ar); 6,3 (d, 1, H-Ar); 5,2 (s, 2, H, $\left.-\mathrm{CH}_{2}\right) ;{ }^{13} \mathrm{C}$ NMR (75 $\left.\mathrm{MHz}, \mathrm{CDCl}_{3}\right)$ : $\delta$, ppm: 153, 144.8, 142.8, 134.9, 134, 132.6, 131.2, 120.9, 117.2, 110, 109.2, 56.4. FTIR max/ $/ \mathrm{cm}^{-1}: 3007$ (C-H), 2226 (C-N), 1678, 1593 (C-C), 1435, 1408, 1397 (C$\mathrm{H}) 884,666(\mathrm{O}=\mathrm{S}=\mathrm{O}) 1150$ and 1320 Anal calculated for $\mathrm{C}_{13} \mathrm{H}_{8} \mathrm{O}_{3} \mathrm{~N}_{2} \mathrm{~S}$ : C, 57.35; H, 2.94; N, 10.30; S, 11.76\%; Found:
C, 57.43; H, 2.82, N, 10.34; S, 11.65\%. Mass m/z (EI, 30 $\mathrm{eV}): \mathrm{M}^{+} 272$.

\subsubsection{2, 10, 16, 24-Tetrakis 4-((furan-2-ylméthyl) thio)} phthalocyanine zinc (II) (5)

A mixture of compound $3(0.2 \mathrm{~g}, 0.448 \mathrm{mmol})$, anhydrous zinc acetate $\mathrm{Zn}(\mathrm{OAc})_{2} \quad(0.097 \mathrm{~g}, 0.448 \mathrm{mmol})$ and 1,8diazabicyclo[5.4.0] undec-7-ene (DBU) $(0.1 \mathrm{~mL}, 0.67 \mathrm{mmol})$ in dry 1-pentanol $(2 \mathrm{~mL})$ was stirred and heated at reflux temperature under an argon atmosphere for $12 \mathrm{~h}$. After cooling to room temperature, the reaction mixture was precipitated by adding it drop wise into n-hexane. The crude product was precipitated, collected by filtration and washed with hot hexane, ethanol and methanol. The crude green product was further purified by chromatography over a silica gel column using DCM and a mixture of $\mathrm{DCM}-\mathrm{C}_{2} \mathrm{H}_{5} \mathrm{OH}$ (10:1 by volume), as eluents. The product is soluble in DMF, THF, $\mathrm{CHCl}_{3}, \mathrm{DCM}, \mathrm{DMSO}$ and water. Yield: $(52 \%) .{ }^{1} \mathrm{H} \mathrm{NMR}(300$ $\mathrm{MHz}, \mathrm{CDCl}_{3}$ ): $\delta$, ppm: 9.2 (m, 12, H-Ar); 7.6 (m, 4, H-Ar); 6.4 (d, 4, H-Ar); 6,1 (d, 4, H-Ar); 4,5 (s, 8, - $\left.\mathrm{CH}_{2}\right)$; FTIR $\max / \mathrm{cm}^{-1}$ : $3098(\mathrm{C}-\mathrm{H}), 1668,1590$ (C-C), 1437, 1408, 1387 (C-H), 726 (C-S-C). UV-Vis (DMF) $\lambda_{\max }$ nm (loge): 360(5,07), 619(4,75), 686(5,40). MALDI-TOF-MS m/z: Calc: 1017.59; Found $[\mathrm{M}]^{+}: 1017.46$.

\subsubsection{2, 10, 16, 24-Tetrakis 4-((furan-2-ylméthyl) sulfonyl) phthalocyanine zinc (II) (6)}

The procedure is the same with the synthesis of compound $\mathbf{5}$, except it is the compound 4 that will be used instead of compound 3. The product is soluble in DMF, THF, $\mathrm{CHCl}_{3}$, DCM, DMSO and water. Yield (33\%). ${ }^{1} \mathrm{H}$ NMR(300 MHz, $\mathrm{CDCl}_{3}$ ): $\delta$, ppm: 9.6 (m, 12, H-Ar); 8.1 (m, 4, H-Ar); 6.5 (d, 4, H-Ar); 6,3 (d, 4, H-Ar); 4,7 (s, 8, - $\mathrm{CH}_{2}$ ); FTIR max/cm ${ }^{-1}$ : 3098 (C-H), 1668, 1590 (C-C), 1437, 1408, 1387 (C-H), 728 (C-S-C). UV-Vis (DMF) $\lambda_{\max } \quad \mathrm{nm} \quad(\log \varepsilon): \quad 347(4,71)$, 613(4,36). MALDI-TOF-MS m/z: Calc: 1145.60; Found $[\mathrm{M}]^{+}: 1145.45$.

\subsubsection{Antibacterial effect of compounds}

In order to study the antibacterial activity of the following synthesized compounds: phthalocyanine bearing 4-((furan-2ylméthyl) thio) 5 and 4-((furan-2-ylméthyl) sulfonyl) 6. We have chosen two types of bacteria Staphylococcus aureus (ATCC 9144) which is a gram (+) and Vibrio anguillarum (ATCC 12964T) classified gram (-).

The compounds $\mathbf{5}$ and $\mathbf{6}$ were solubilized in a distilled water solution. The two phthalocyanines solutions are mixed in $100 \mathrm{~mL}$ of bacterial broths with two doses of $10 \mathrm{~mL}$ and 50 $\mathrm{mL}$, thereafter the solutions were placed in an oven for 3 hours with an artificial light. $1 \mathrm{ml}$ of every dilution (broths) are plated on Petri dishes and incubated in an oven at $37^{\circ} \mathrm{C}$ for 24 hours. Finally, after the counting, results are expressed as decimal logarithm of CFU / $\mathrm{mL}$

\section{Volume 5 Issue 6, June 2016 www.ijsr.net}




\section{Results and discussion}

\subsection{Synthesis and characterization}

The synthetic route followed for the synthesis of new dinitriles compounds $(\mathbf{3}, \mathbf{4})$ and novel derivatized zinc(II) phthalocyanines complexes $(\mathbf{5}, \mathbf{6})$ is given in Scheme $\mathbf{1}$

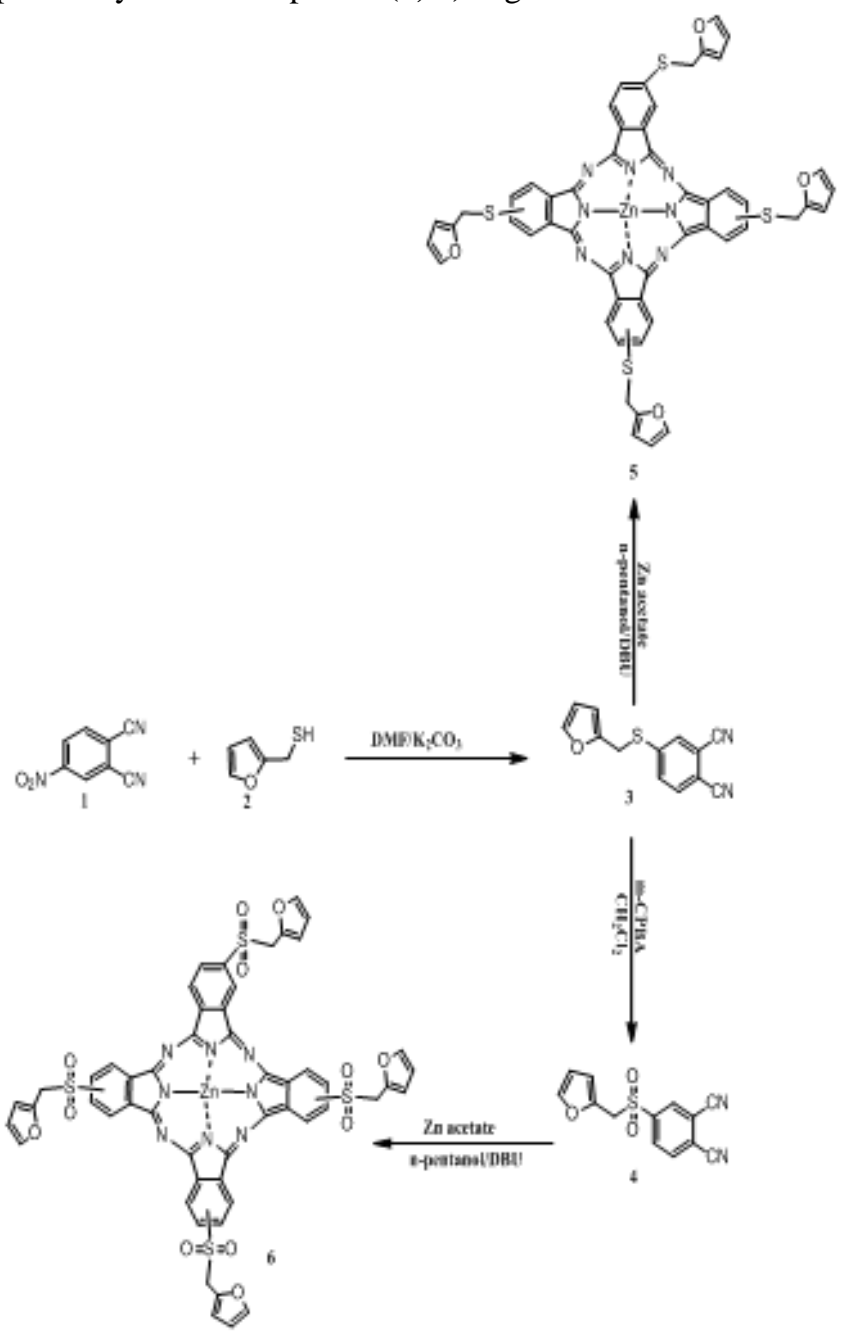

Scheme 1: The route for the synthesis of compound 3-6

The procedure for the synthesis of compound $\mathbf{3}$ was similar to that used for many examples in literature [20], [21]. Phthalonitrile derivative $\mathbf{3}$ was prepared from 4nitrophthalonitrile 1 by nucleophilic substitution of the nitro groups with the $\mathrm{SH}$ function of furan-2-méthylthiol 2 via $\mathrm{S}_{\mathrm{N} 2}$ reaction in polar aprotic dry solvents (DMSO or DMF) [22], [23] in the presence of potassium carbonate as basic catalyst $\mathrm{K}_{2} \mathrm{CO}_{3}$ with $90 \%$ yield. The resulting 4-((furan-2-ylméthyl) thio) phthalonitrile 3 was then oxidized by oxidant such as m-chloroperbenzoic acid ( $m$-CPBA) or hydrogen peroxide $\left(\mathrm{H}_{2} \mathrm{O}_{2}\right)$ [24] to lead to the expected 4-((furan-2-ylméthyl) sulfonyl) phthalonitrile 4 . Then the self-condensation of dinitrile derivatives $\mathbf{3}$ and $\mathbf{4}$ in a high-boiling solvent (npentanol) in the presence of a few drops 1,8diazabicyclo[5.4.0]undec-7-ene DBU as a strong base and anhydrous $\mathrm{Zn}\left(\mathrm{CH}_{3} \mathrm{COO}\right)_{2}$ at reflux temperature under a nitrogen atmosphere afforded the zinc phthalocyanines $\mathbf{5}$ and 6. Purification of the novel synthesized phthalocyanines was achieved by column chromatography on silica gel by using $\mathrm{CH}_{2} \mathrm{Cl}_{2}$ and $\mathrm{C}_{2} \mathrm{H}_{5} \mathrm{OH}$ mixtures as the eluent. With regard to the solubility of the new phthalocyanines, both compounds have best solubility in almost all organic solvents. The structures of new compounds were confirmed by the combination of UV-visible, IR, ${ }^{1} \mathrm{H}$ NMR, ${ }^{13} \mathrm{C}$ NMR, MS spectroscopic data and elemental analysis. Spectral investigations of the dinitrile derivative show good agreement with proposed structures. When IR spectrum of compound $\mathbf{1}$ is compared with that of compound $\mathbf{3}$, a distinct difference is the disappearance of the aromatic $\mathrm{NO}_{2}$ band at $1546 \mathrm{~cm}^{-1}$. The $-\mathrm{C} \equiv \mathrm{N}$ vibration and the thioether $(\mathrm{C}-\mathrm{S}-\mathrm{C})$ vibrations for compound $\mathbf{3}$ were observed respectively about $2226 \mathrm{~cm}^{-1}$ and $730 \mathrm{~cm}^{-1}$. After oxidation of compound 3 to compound 4, the comparison of their IR spectra highlighted the apparition of the $\mathrm{O}=\mathrm{S}=\mathrm{O}$ large vibrations around 1150 and $1320 \mathrm{~cm}^{-1}$. Also, the melting points of nitrile increased.

In addition, the ${ }^{1} \mathrm{H}$ NMR spectra of compound $\mathbf{3}$ are not the same as of compound 4. While the aromatic protons of compound $\mathbf{3}$ appear at 7.5-7.7 ppm, the aromatic protons of compound 4 are shifted at 8.6-8.2 ppm showing the increase of electron-withdrawing character of substituents upon oxidation to $\mathrm{SO}_{2} \mathrm{R}$. Stable molecular ion $[\mathrm{M}]^{+}$peaks $\mathrm{m} / \mathrm{z}$ at 240 and 272 in the mass spectra of compounds $\mathbf{3}$ and $\mathbf{4}$ were reflected that target compounds were successfully prepared. Also elemental analysis data of these compounds 3 and 4 were satisfactory. The most important proof of the cyclotetramerization of nitrile groups is the absence of the $\mathrm{C} \equiv \mathrm{N}$ vibrations at $2226 \mathrm{~cm}^{-1}$ in IR spectra of the substituted phthalocyanine compounds (6 and 5). The rest of the spectra were not very different from that of the corresponding phthalonitrile compounds.

\subsection{Ground state electronic absorption and aggregation properties}

The UV-visible spectroscopy is a very useful technique for the determination of the structural properties and aggregation phenomena of phthalocyanines in both solution and solid state [25]. Generally, phthalocyanine exhibited characteristic $\mathrm{Q}$ and $\mathrm{B}$ bands in the electronic spectra at ultraviolet and visible region [26].One of them is called as $\mathrm{Q}$ band observed at around $600-700 \mathrm{~nm}$ which is attributed to the $\pi \pi^{*}$ transition from the highest occupied molecular orbital (HOMO) to the lowest unoccupied molecular orbital (LUMO) of the phthalocyanine ring. The other is called Soret or B band observed at around 300-350 nm, arising from the deeper $\pi$ levels to the LUMO transition [27-28-2930].The newly synthesized zinc phthalocyanines (5 and 6) had the best solubility in many organic solvents, such as dichloromethane (DCM), dimethylformamide (DMF), dimethylsulfoxide (DMSO), methanol, tetrahydrofuran (THF) and water. 
International Journal of Science and Research (IJSR)

ISSN (Online): 2319-7064

Index Copernicus Value (2013): 6.14 | Impact Factor (2015): 6.391

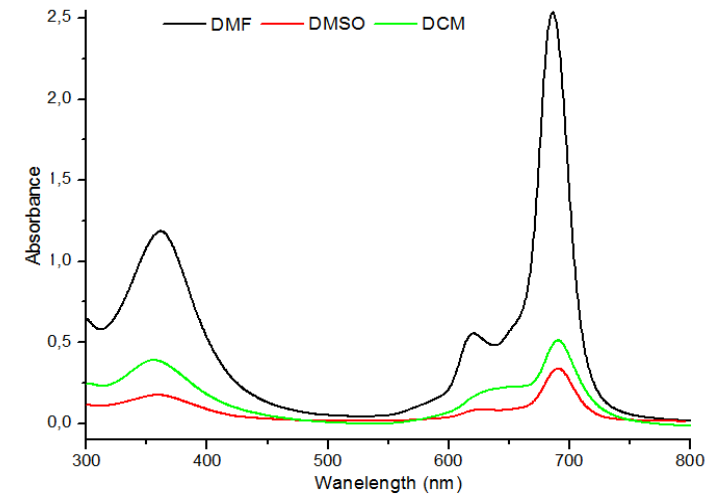

Figure 1: UV-vis absorption spectra 5 in different solvents

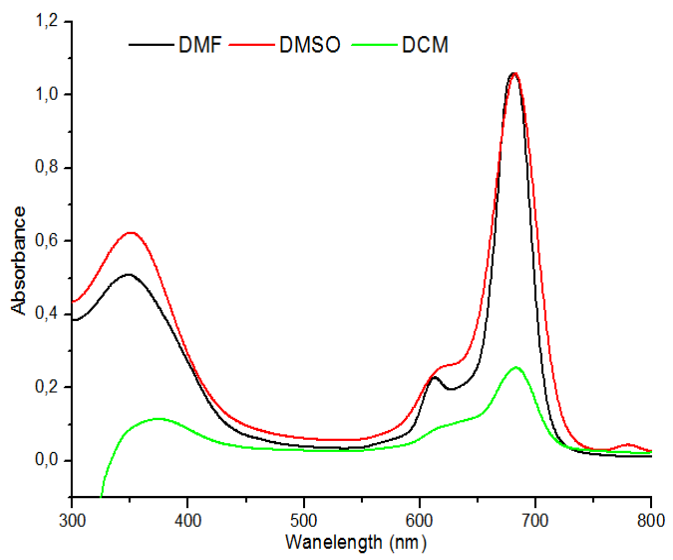

Figure 2: UV-vis absorption spectra 6 in different solvents

The spectral profiles of the two phthalocyanine compounds were recorded in three organic solvents DMF, DMSO and DCM having wide variety of solvent parameters such as dielectric constant $\varepsilon$, refractive index $\mathrm{n}$ and solvatochromic parameters $\alpha, \beta$ and $\pi^{*}$.

The spectra of two phthalocyanines 5 and $\mathbf{6}$ in various organic solvents are presented in respectively Figure $\mathbf{1}$ and 2. It is obvious that there is considerable change in absorption profile of the molecules with variation in polarity of the medium. The given compounds (5 and 6) possess bathochromic spectral shifts (positive solvatochromism) while moving from least polar solvent (DMSO) to the most polar solvent (DCM). This is attributed to the fact that molecule in the ground state and excited state possesses different polarities. The compounds with non-polarized ground state are strongly polarized in aprotic solvents since the high energy polar structure of excitation state is stabilized. Absorption and extinction coefficients are presented in Table 1, and the UV-visible spectra are shown in Figure $\mathbf{1}$ and 2. They exhibited typical electronic absorption with single intense $\pi$ - $\pi^{*}$ transition, referred to as the $\mathrm{Q}$ band, much intense and characteristic for phthalocyanines, and another less intense and broader $\pi$ - $\pi^{*}$ transition which is so-called Soret band (B).
Table 1: UV-visible data for the phthalocyanine compounds

\begin{tabular}{|c|c|c|c|}
\hline \multirow{2}{*}{ Compound } & \multirow{2}{*}{ Solvent } & \multicolumn{2}{|c|}{$\lambda$ max nm $(\log \varepsilon)$} \\
\cline { 3 - 4 } & & B band & Q band \\
\hline \multirow{3}{*}{5} & DMF & $360(5,07)$ & $619(4,75), 686(5,40)$ \\
\cline { 2 - 4 } & DMSO & $359(4,26)$ & $627(3,99), 689(4,71)$ \\
\cline { 2 - 4 } & DCM & $356(4,59)$ & $639(4,34), 691(4,70)$ \\
\hline \multirow{3}{*}{6} & DMF & $347(4,71)$ & $613(4,36), 679(5,02)$ \\
\cline { 2 - 4 } & DMSO & $349(4,80)$ & $619(4,42), 681(5,03)$ \\
\cline { 2 - 4 } & DCM & $366(4,06)$ & $621(3,94), 683(4,41)$ \\
\hline
\end{tabular}

The absorption spectrum of compound 6 in DMSO and DMF showed two narrow peaks of about equal intensity at $679 \mathrm{~nm}$ and $681 \mathrm{~nm}$ which is not the case for compound $\mathbf{5}$ where an important reduction of the intensity of the band $\mathrm{Q}$ in the DMSO was recorded. Sharp and single Q bands of compounds 5 and 6 in DMF and DMSO are typical of nonaggregated monomoric in both solvents, but aggregated in DCM as evidence by its broad, decreased and red-shifted Q band. In accordance with Kasha's exciton theory [31], [32] it may imply that phthalocyanine $\mathbf{5}$ and $\mathbf{6}$ forms $\mathbf{J}$ aggregates in DCM.

A comparison of the position of the $\mathrm{Q}$ band maximum of compounds $\mathbf{5}$ and $\mathbf{6}$, bearing respectively electronwithdrawing and electron-donating substituents, reveals that compound 6 exhibits a blue shifted Q band nearly $8 \mathrm{~nm}$ compared to compound $\mathbf{5}$ in solvents, due to the electron withdrawing nature of sulfonyl groups in compound $\mathbf{6}$.

The UV-visible spectra data presented in Table.1 show that all investigated macrocycles $\mathbf{5}$ and $\mathbf{6}$ are monomeric in DMF. The DMF is a solvent having electron donor atoms binding through the double-bonded oxygen atom to the $\mathrm{Zn}$ metal of the $\mathrm{ZnPc}$ monomer. Hence, it interacts by coordination with central metal cation of phthalocyanine macrocycle which explains the highest DMF solvation compared to other solvents. Besides, DMF has specific solvation ability toward peripheral substituents of phthalocyanine due to its donoracceptor properties [33], [34].

The phthalocyanine spectrum analysis showed a band at 775 $\mathrm{nm}$ only in DMSO. The origin of this new band was explained in terms of the distortion of sulfonyl substituted ZnPc complexes 6 ring in DMSO. The reason why the 775 $\mathrm{nm}$ was clearly observable in DMSO may be due not only to the interaction by the oxygen at the axial position of $\mathrm{ZnPc}$ complexes enhancing the distorsion [35] but also to the interaction of the furan group. The local DMSO concentration around furan group may be highly increased with the increment of sulfonyl group on the furan moiety and skeleton of the phthalocyanine 6 ring.

The results of the DFT calculated adsorption energies for all solvents binding to the $\mathrm{Zn}$ metal of the $\mathrm{ZnPc}$ monomer reported, by N. L. Tran [36], that the basic DCM is the weakest binder to ZnPc with a DFT calculated which explain the aggregation of the two compounds 5 and $\mathbf{6}$ (Figure $\mathbf{1}$ and 2 ) in DCM solvent. 


\section{International Journal of Science and Research (IJSR) \\ ISSN (Online): 2319-7064}

Index Copernicus Value (2013): 6.14 | Impact Factor (2015): 6.391

The strongest binder DMSO results in the greatest transfer of electrons to the $\mathrm{ZnPc}$ monomer compared to the weakest binder DCM results in a charge transfer to the $\mathrm{ZnPc}$ monomer, which agrees well with our found results. Therefore, it is possible to control the monomer-dimer equilibrium and hence to carry out the directed formation of supramolecular phthalocyanine systems by amplification/reduction of solvating power of the medium. Aggregation, usually defined as a coplanar association of rings progressing from monomer to dimer or higher order complexes [37], is dependent on the strong $\pi-\pi$ electron interaction of the macrocycles, coloumbic forces, the solvent used and the concentration of the dissolved phthalocyanine, the nature and the connection of the substituents, coordinated metal ions and temperature [38]. The aggregation process of phthalocyanines can easily be probed using electronic spectroscopy [39]. On another hand, phthalocyanines are known by their distinctive ability to form several types of aggregates, mainly $\mathrm{H}$-aggregates and J-Aggregates, on solid supporting surfaces and in solutions. Aggregate formation is accompanied by dramatic changes in the absorbance of metallophthalocyanines.

In the case of H-aggregates, a broad blue shift absorbance is observed, while the J-aggregates are distinguished by a narrow, red shift absorbance band, relative to the monomeric dye, in the visible region. Solvents also affect the photophysical and photochemical properties of metallophthalocyanines [40], [41] and have a great influence on self-association of metallophthalocyanines in solution [42], [43]. It has been well established that non-aggregated phthalocyanines are extremely important for their many applications [44], [45].

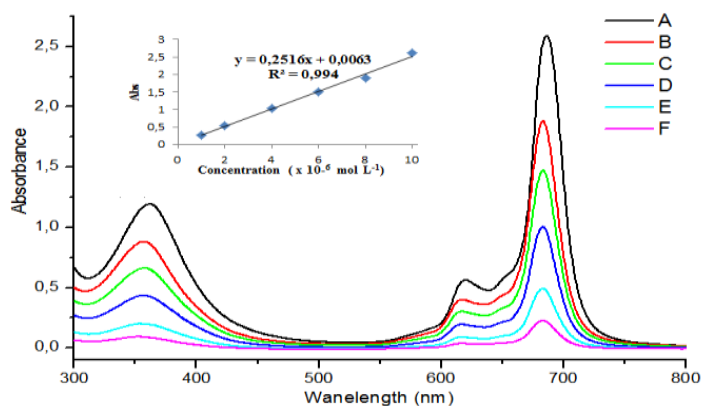

Figure 3: Aggregation behavior of 5 in DMF at different concentrations: $1.10^{-5}(\mathbf{A}), 8.10^{-6}(\mathbf{B}), 6.10^{-6}(\mathbf{C}), 4.10^{-6}(\mathbf{D})$, $2.10^{-6}(\mathbf{E}), 1.10^{-6}(\mathbf{F})$, mol.L ${ }^{-1}$

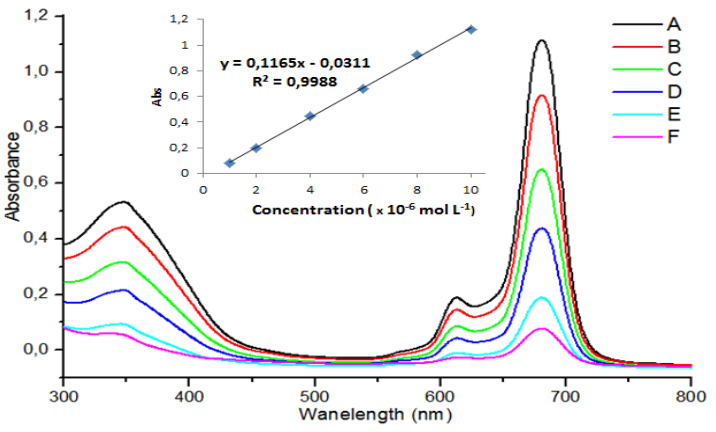

Figure 4: Aggregation behavior of 6 in DMF at different concentrations: $1.10^{-5}(\mathbf{A}), 8.10^{-6}(\mathbf{B}), 6.10-6(\mathbf{C}), 4.10^{-6}(\mathbf{D})$, $2.10^{-6}(\mathbf{E}), 1.10^{-6}(\mathbf{F})$, mol.L ${ }^{-1}$

In this study the aggregation behavior of the complexes 5 and $\mathbf{6}$ has been examined by concentration dependent UVVisible spectra measurements in DMF (Figure 3 and 4). As the concentration was increased, the intensity of absorption of the $\mathrm{Q}$ band also increased and there were no new bands (normally blue shifted) due to the aggregated species [46], [47]. The derivatives 5 and $\mathbf{6}$ did not show aggregation in DMF. The Beer-Lambert law was obeyed for all of these compounds in DMF for the concentrations ranging from $10^{-6}$ to $10^{-5} \mathrm{~mol} \cdot \mathrm{L}^{-1}$.

\subsection{Antibacterial activity}

The results shown in the following tables (Table 2 and 3) indicate the existence of a significant antibacterial effect of phthalocyanines on the growth of staphylococcus bacteria and Vibrio. We have also noted a significant effect according to the biochemical composition of the bacterial wall. This could be explained by the oxidation phenomenon which differs from a two-layer structure gram $(+)$ to a triple layer structure gram (-) [48].

Table 2: Effect of compound $\mathbf{5}$ on Vibrio anguillarum and Staphylococcus aureus

\begin{tabular}{|c|c|c|c|c|c|c|c|c|}
\hline & \multicolumn{2}{|c|}{0 hour } & \multicolumn{2}{|c|}{1 hour } & \multicolumn{2}{|c|}{2 hours } & \multicolumn{2}{|c|}{3 hours } \\
\hline $\mathrm{mg} / 100 \mathrm{~mL}$ & $\mathrm{CFU} / \mathrm{mL}$ & $\log \mathrm{CFU} / \mathrm{mL}$ & $\mathrm{CFU} / \mathrm{mL}$ & $\log \mathrm{CFU} / \mathrm{mL}$ & $\mathrm{CFU} / \mathrm{mL}$ & $\log \mathrm{CFU} / \mathrm{mL}$ & $\mathrm{CFU} / \mathrm{mL}$ & $\log \mathrm{CFU} / \mathrm{mL}$ \\
\hline no Pc & 362241539 & 8.55 & 385524284 & 8.58 & 415257682 & 8.61 & 583559671 & 8.76 \\
\hline & & & 283556892 & 8.45 & 172495 & 5.23 & 388 & 2.58 \\
\hline 10 & & & 41235684 & 7.61 & 15612 & 4.19 & 57 & 1.75 \\
\hline & & & 2527647 & 6.40 & 1317 & 3.11 & 91 & 1.95 \\
\hline 50 & & & 22453 & 4.35 & 1011 & 3.00 & 7 & 0.84 \\
\hline
\end{tabular}

Vibrioanguillarum (ATCC 12964T)

Staphylococcus aureus (ATCC 9144) 


\section{International Journal of Science and Research (IJSR) \\ ISSN (Online): 2319-7064}

Index Copernicus Value (2013): 6.14 | Impact Factor (2015): 6.391

Table 3: Effect of compound $\mathbf{6}$ on Vibrio anguillarum and Staphylococcus aureus

\begin{tabular}{|c|c|c|c|c|c|c|c|c|}
\cline { 2 - 9 } \multicolumn{1}{c|}{} & \multicolumn{2}{c|}{ O hour } & \multicolumn{2}{c|}{ 1 hour } & \multicolumn{2}{c|}{ 2 hours } & \multicolumn{2}{c|}{ 3 hours } \\
\hline \multirow{2}{*}{ mg/100mL } & \multirow{2}{*}{ CFU/mL } & $\log$ CFU/mL & CFU/mL & $\log$ CFU/mL & CFU/mL & $\log$ CFU/mL & CFU/mL & log CFU/mL \\
\hline \multirow{2}{*}{$\mathbf{1 0}$} & 566587722 & 8.75 & 623357989 & 8.79 & 715654231 & 8.85 & 793365421 & 8.89 \\
\hline \multirow{2}{*}{$\mathbf{5 0}$} & & & 58546211 & 7.76 & 15655 & 4.19 & 6 & 0.77 \\
\cline { 4 - 10 } & & & $\mathbf{5 8 5 4 6 2}$ & $\mathbf{5 . 7 6}$ & $\mathbf{3 0 1}$ & $\mathbf{2 . 4 7}$ & $\mathbf{0}$ & $\mathbf{0 . 0 0}$ \\
\hline
\end{tabular}

Vibrioanguillarum (ATCC 12964T)

Staphylococcus aureus (ATCC 9144)

As well as, we can clearly distinguish the effectiveness of bacterial inhibition of the compound $\mathbf{6}$ vs. compound $\mathbf{5}$, which is explained by the fact that 4- (furan-2-ylsulfonyl) contains more conjugation which allows it to release more singulet oxygen under the effect of light and which causes oxidation of the bacterial wall; hence a good efficiency to inhibit the bacterial multiplication.

\section{Conclusion}

Novel substituted phthalocyanines were synthesized such as Zinc (II) phthalocyanines bearing 4-((furan-2-ylméthyl) thio) and 4-((furan-2-ylméthyl) sulfonyl) substituents and characterized. A comprehensive investigation of the effects of solvents on the aggregation and antibacterial activity was carried. DMSO has proved to be a solvent which behaves quite differently from the rest of the solvents such DCM. We have also noted a significant effect according to the biochemical composition of the bacterial wall. This could be explained by the oxidation phenomenon which differs from a two-layer structure $(\mathrm{Gram}+)$ to a triple layer structure (Gram-).

\section{References}

[1] B.Simic-Glavaski, C. C. Leznoff, A. B. P. Lever, (Eds.) Phthalocyanines-Properties; Applications. VCH. Vol 3; New York, 1993, 119.

[2] Segalla, A., Borsarelli,C.D., Braslavsky, S.E., Spikes, J.D., Roncucci,G., Dei,D.,Chiti,G., Jori, G., Reddi, E. Photochem. Photobiol. Sci., 2002 (1) 641-648

[3] Jancula, D., Marsalek, B. Chemosphere. 2012 (88) 962 965.

[4] J. J. R. Fraústo da Silva, R. J. P. Williams, (Eds.) The Biological Chemistry of the Elements-The Inorganic Chemistry of Life Clarendon Press, Oxford, 1991, 343.

[5] S. Jesenska, L. Plistil, P. Pavel Kubat, K. Lang, Brozova, L., Popelka, Š., Szatmary, L., Mosinger,. J. Biomed. Materials Res. (4). 2011 .676-683

[6] Minnock, A., Vernond. I., Schofield, J., Griffiths, J., Parish, J. H., Brown, S. B. J. Photochem. Photobiol. B: Biol. 1996 32. 159 - 164.

[7] M. Salih Agırtas, M. Emin Güven, Selcuk Gümüs, Sadin Özdemir, Abdurrahman Dündarc. Synthetic Metals (195) 2014, 177-184

[8] M. Celebi, M. Salih Agırtas, V. Okumus, S. Ozdemir.. Synthetic Metals (195) .2014.154-161
[9] R. Bayrak, H.Türker Akçay, F. Şaban Beriş, E. Şahin, H. Bayrak, Ü. Demirbaş. Spectrochimica Acta Part A: Molecular and Biomolecular Spectroscopy 2014

[10]H. B. Yahia Smida, B. Jamoussi. Journal of Applied Chemistry (IOSR-JAC) Vol 2, Issue 3, 2012, 11-17

[11] S. Touaiti, A. Hajri, M. S. Kahouech, J. Khiari, B. Jamoussi. Arabian Journal of Chemistry 2013

[12] A. Hajri, S. Touaiti, B. Jamoussi. Hindawi Publishing Corporation Advances in OptoElectronicsVolume 2013

[13] M.S. Kahouech K. Hriz S. Touaiti J. Bassem. Materials Research Bulletin Vol 75, 2016, 144-154

[14] C.C. Leznoff, A.B.P. Lever, Phthalocyanines properties and applications, New York: VCH Publisher vol.1; 1989.

[15] M. Bouvet, Anal Bioanal Chem. 2006, 384, 366-73.

[16] A. Ogunsipe, T. Nyokong. Journal of Molecular Structure 689(1-2):89-97

[17] N. Nombona, K. Maduray, E. Antunes, A. Karsten, T. Nyokong, J Photochem Photobiol B: Biol 2012, 107, 3544.

[18] M. Durmus, T. Nyokong, Tetrahedron. 63, 2007, 138594.

[19] J.G. Young, W. Onyebuagu, J. Org. Chem. 55. 1990. 2155-2159.

[20]H.Y. Yenilmez, A.I. Okur, A. Gül, Journal of Organometallic Chemistry 692, 2007, 940-945.

[21] I. Deðirmencioðlu, E. Atalay, M. Er, Y. Köysal, S. Ipýk, K. Serbest, Dyes and Pigments 84. 2010. 69-78

[22] V. Chauke, M. Durmus, T. Nyokong, Journal of Photochemistry and Photobiology A: Chemistry 192. 2007. 179-187.

[23] R. Bayrak, H.T. Akcay, M. Durmup, I. Deðirmencioðlu, Journal of Organometallic Chemistry 696. 2011. 38073815.

[24] Sastre A, del Rey B and Torres T. J. Org. Chem.61; 1996. 8591-8597.

[25] S. Makhseed, J. Samuel, Dyes Pigments 82, 2009.

[26] A.M. Sevim, Y. Arslano glu, E. Hamuryudan, A. Gül, Dyes and Pigments 68 (2006)129-132.

[27] T. Nyokong, H. Isago, J. Porph. Phthal. 8; 2004. 10831090.

[28] M. Sommerauer, C. Rager, M. Hanack, Journal of the American Chemical Society118; 1996. 10085-10093.

[29] A. Kalkan, Z.A. Bayır, Polyhedron, 25; 2006. 39-42.

[30] A. Koca, A. Kalkan, Z.A. Bayır, Electrochimica Acta, 56; 2011. 5513-5525.

[31] M. Kasha, Radiat. Res., 1963, 20, 55

[32] M. Kasha, H. R. Rawls and M. A. EI-Bayoumi, Pure Appl.Chem., 1965, 11, 371. 


\section{International Journal of Science and Research (IJSR) \\ ISSN (Online): 2319-7064}

Index Copernicus Value (2013): 6.14 | Impact Factor (2015): 6.391

[33] Gutman, V., Schmid, R., Coord. Chem. Rev.3; 1974. 263.

[34] Mayer, U., A semiempirical model for the description of solvent effects on chemical reactions, Pure \& Appl. Chem; 51. 1979. 1697.

[35] K. Kasuga, N. Matsuura, K. Inoue, M. Handa, T. Sugimori, K. Isa, M. Nakata, Chem. Lett. 2002.352.

[36] N. L. Tran, F. I. Bohrer, W. C. Trogler, and A. C. Kummela . The journal of chemical physics; 130; 2009

[37] N. Nombona, T. Nyokong, Dyes Pigments.80; 2009. 130-135

[38] H. Enkelkamp, R.J.M. Nolte, J. Porphy. Phthalocyan. 4; 2000. 454-459.

[39] J.L. Sessler, J. Jayawickramarajah, A.Gouloumis, G.D. Pantos, T. Torres, D.M.Guldi, Tetrahedron; 62; 2006. 2123

[40] W.-F. Law, R.C.W. Liu, J. Jiang, D.K.P. Ng, Inorg. Chim. Acta 256,1997, 147.

[41] M.P. Somashekarappa, J. Keshavayya, Synth. React. Inorg. Met.-Org. Chem. 31 (2001) 811.

[42] Lukyanets, E. A., Nemykin, V. N., J. Porphyrins Phthalocyanines, 2010, 14, 1

[43] L., Jing, L., Lin, Sh., Deng, X., Zhu, P., Zhang, X., Dyes and Pigments, 2014, 106, 176.

[44]E. Güzel, A. Atsay, S. Nalbantoglu, N. S, aki, A.L. Dogan, A. Gül, M.B. Koçak, Dyes Pigm. 97; 2013. 238243.

[45] X. Fang, J.D. Wang, M.J. Lin, J. Mol. Catal. B Chem. 372. 2013. 100-104.

[46] C.C. Leznoff, A.B.P. Lever, Phthalocyanines Properties and Applications, VCH, Weinheim, 1989.

[47] A.W. Snow, N.L. Jarwis, J. Am. Chem. Soc. 106; 1984. 4706-4711.

[48] A. Minnock, David I. Vernon, J. Schofield, J. Griffiths, j. Howard Parish,Stanley B. Brown Journal of Photochemistry and Photobiology B: Biology 32; 1996. 159-164. 